Aleksandr N. Andreev and Yulia S. Andreeva

\title{
Reunification of the Uniates of Malorossiya (Ukraine) and Belarus with the Russian Orthodox Church: A View from Inside (Based on Memoirs of the Late $18^{\text {th }}$ Century)
}

\author{
Reunifikacija maloruskih (ukrajinskih) in beloruskih \\ uniatov z Rusko pravoslavno Cerkvijo: pogled od zno- \\ traj (na podlagi spominov s konca 18. stoletja)
}

Abstract: The purpose of this article is to provide an objective study of the process of the return of the Uniates (Greek Catholics) to the Russian Orthodox Church in lands which departed from the Polish Commonwealth to the Russian Empire. Historiography has strengthened the view that the transitions of the Uniates to Orthodoxy have always been voluntary and even desirable. At the same time, historians utilized numerical data on conversions to Orthodoxy, very rarely utilizing primary sources. The analysis of memoirs (the writings of government officials on whom the implementation of the policy of religious appeals depended) undertaken in this article, shows that, in fact, there were protests from the Uniate population against violent Orthodoxy. The systemic approach (the method of structural systematization) is utilized in our work, making it possible to examine interconfessional relationships both from the positions of representatives of the authorities and from the Uniate community.

Key words: Uniates, Russian Orthodox Church, Malorossiya, Belarus, inter-confessional relations, reunification

Povz̨etek: Namen tega članka je ponuditi objektivno študijo o procesu vrnitve uniatov (grkokatolikov) v Rusko pravoslavno Cerkev na ozemljih, ki so pripadla Ruskemu imperiju in so bila prej del poljsko-litovske države. Zgodovinopisje je doslej poudarjalo stališče, da so bili prehodi uniatov v pravoslavje vselej prostovoljni in celo hoteni. Obenem so se zgodovinarji sklicevali na numerične podatke o spreobrnitvah v pravoslavje, vendar so pri tem zelo redko uporabljali primarne vire. Analiza spominov (zapisov državnih uslužbencev, od katerih je bilo odvisno uresničevanje verske politike), ki se jim v tem članku posvečamo, pa $v$ resnici kaže na proteste uniatskega prebivalstva proti nasilnemu pravoslav- 
ju. $V$ tem delu uporabljamo sistemski pristop (metodo strukturne sistematizacije), s katerim je mogoče preučiti medkonfesionalne odnose tako s stališča predstavnikov oblasti kakor tudi uniatske skupnosti.

Ključne besede: uniati, Ruska pravoslavna Cerkev, Mala Rusija, Belorusija, medkonfesionalni odnosi, reunifikacija

\section{Introduction}

The scale and cruelty of the persecution and violence suffered by Orthodox subjects of the Polish Commonwealth (Rzeczpospolita) in the 17th and 18th centuries invariably shocked Orthodox researchers. Many interesting works have been devoted to this topic with references to reliable documentary materials (Bantysh-Kamenskij 1864, 305; 369-399; Simaškevič 1872, 111; Maraš 1971, 184). The compulsion among Orthodox believers to join the Uniate law, indeed, was determined by the very logic of the development of Orthodox-Catholic relations in Eastern Poland in the 18th century; however, along with this, there was also the reverse side of the problem, which historians, for political and ideological reasons, still prefer not to pay attention to. The sources, as will be shown below, make it possible to assert that after the partitions of the Polish state, the Catholics of the Eastern Rite, who found themselves in Russia, also often became the object of attack by the Russian imperial state apparatus. History justifies the long-standing truth: cujus regio ejus religio, but, unfortunately, the political urgency of the issues raised in this article still hinders their objective comprehension in the scientific community.

The thesis on the anti-Catholic and anti-Uniate sentiments of the Orthodox inhabitants of Poland (both before and after its partitions) has long become common place for Russian historiography, unquestioned and criticized (Anisimov et al. 2007, 19-24). The mutual struggle between Catholicism and Orthodoxy, evident for contemporaries, was taken by historians as the only possible model of inter-confessional relations in the former Polish domain. When Georgy Konyssky submitted a report to the Foreign Affairs Board which cited information about the ruin of more than two hundred Orthodox churches in Poland over the course five years in July 1765, the scale of the oppression of the Orthodox Church impressed even the Catherine's dignitaries who had seen a lot (Stegnij 2001, 166). Despite real oppression of the Orthodox in Poland, archival documents and especially primary sources show the contradictory, rather than unequivocally negative, attitude of the Orthodox population of the Belarusian-Lithuanian lands towards Catholicism and the Uniate Church. The inconsistency of the Orthodox dogma and the historical (inherited) hatred of the Orthodox towards Catholicism and the union is confirmed by the facts from the religious life of the Khmelnitsky family. Hetman Bogdan Khmelnitsky, discussing truce matters, demanded that the authorities of the Polish-Lithuanian Commonwealth order the destruction of the ecclesiastical Union in the Kiev province and the deportation of Jesuits (Zaborovskij 1998, 32). 
However, Vasko Vozshilo, Khmelnitsky's grandson, who raised an uprising of peasants against usury Jews in 1744 in Lithuania, acted in his manifesto on behalf of the ruling Catholic Church (Giltebrandt 1870, 522-524).

\section{The policy of returning the Uniates to Orthodoxy}

During the partitions of the Commonwealth (especially the second and third), the Russian government actively encouraged the transition of Catholics and Uniates to Orthodoxy, although the overall influence of Catholicism in the newly-transitioned regions was not undermined in its entirety. The partitions of Poland initiated the process of returning Russian, Belarusian, and Malorossian (Ukrainian) Catholics and Uniates to their »national « religion. After the first partition, in 1772-1773, entire Uniate parishes expressed a desire to reunite with Orthodoxy: for example, the parishes of the villages of Gorodetsky and Shukai-voda, the village of Krasny Les of the Belotserkovsk volost, and others (RSHA 1772a, 1; RSHA 1772b, 1). Mogilev Orthodox bishop George often reported to the court about many people wishing to move from the Union to Orthodoxy (Iz bumag protoiereja Ioanna Pamfilova 1871, 209-210). In one of his speeches in 1773, the Reverend declared: "Already prisoners in droves, like streams to the South, to Zion, the mother of their Church, are happily returning." (Bulgakov 2000, 262). By 1775, Bishop George had accumulated up to 80 requests for transitions to Orthodoxy, submitted by various Uniate parishes and deans (268). However, the position of the Russian authorities in their relations with Catholics and Uniates remained cautious for a long time. According to the plans of Catherine II, the Uniate Church was not to disappear immediately and completely, and therefore initially the efforts of the main ideologist of the "return of the Uniates to the faith of the ancestors " George (Konyssky) met resistance from the central state apparatus (Bulgakov 2000, 262-274; Lušpaj 2002, 105). At the beginning of 1774, Bishop George received an order from the Saint-Petersburg Holy Synod not to take Uniates to Orthodoxy, despite persistent requests (Smolič 1997, 327). The liquidation of the Uniate Church, which managed to occupy a certain niche in the confessional space of Eastern Poland, threatened to destabilize the region. Realizing this, Catherine II tried to pursue a balanced policy and was afraid to openly violate the religious rights of her new subjects and the existing status quo of local faiths. Uniates were traditionally under the sphere of influence of the preaching efforts of the Jesuits and other orders, and incautious interference in the affairs of the Union could break the relationship with the Roman Curia and European courts. In addition, the excessive distribution of Orthodoxy in Poland, which could become a consequence of the Church reunion of the Eastern Belarusian region, was not beneficial to Russian authorities, as it provoked the flight of peasants from neighboring Russian provinces (Stegnij 2001, 167).

The gradual integration of Eastern Belarus into the Russian Empire, and then the aggravation of the revolutionary situation in Poland, required the government to 
take decisive measures to return the Uniates to Orthodoxy. On July 2, 1780 Catherine II ordered the establishment of a Spiritual Consistory for the administration of Uniate churches in the Polotsk and Mogilev governorships. At the same time, Polotsky Uniate Archbishop Jason Smogorzewski, who became a Uniate Metropolitan in Poland (i.e. head of the entire Uniate Church), was removed from the administration of the Uniate churches in Russia (the Polotsk Archdiocese remained vacant until 1784, and the affairs of the Russian Uniates were ruled by the Polotsk Consistory). The July 2 decree officially permitted the transfer of entire Uniate parishes to Orthodoxy, but only if the priestly place in the parish would be vacant and parishioners voluntarily wished to transfer parish authority to the Orthodox priest:

»In case of a vacancy in any parish priesthood, people are reliable to ask and probably inquire from parishioners, whether they wish to have a priest of our Orthodox Eastern law /... / if the parishioners wish to have a Uniate priest, then the consistory of these churches should be entrusted to the parish priest who is closest to the parish, so long as new priests can be ordained with the decree of the present bishop." (Polnoe sobranie zakonov Rossijskoj imperii 1830, 953-954)

In the same month, personal secretary of the Empress A. A. Bezborodko, arguing in a letter to the St. Petersburg Metropolitan Gabriel about the establishment of the Uniate Consistory and the decisive refusal of the Empress by Jason Smogorzewsky, voiced the official position of the government to the Uniate Metropolitan in Poland who wished to take the Polotsk Uniate chair in Russia: » /... / and a decisive blow to the sect, stemming from the cunning of the Papists and from the extreme ignorance of our faithful." (Grigorovicz 1869, 1620). In $1791 \mathrm{G}$. A. Potemkin made a project to liquidate the Union in Belarus and was supported by Bezborodko (Borisjonok 2003, 117).

Thus, in the 1780s the process of the reunification of the Belarusian population was markedly intensified, and since 1794, when the Uniate Church almost completely fell under the jurisdiction of Russia, the spread of Orthodoxy in Malarossiya and Belarus acquired colossal proportions. It seems that the number of those "rejected by force, but returned by love", according to the expression of Orthodox church historians, eloquently displays the desire of the Uniates to return to the bosom of the Russian Orthodox Church: according to the data of George Konyssky, 112.578 Uniates appealed to Orthodoxy in 1781-1783 in the Mogilev diocese (in $1781-85.069$, in $1782-17.829$, in $1783-9.680$ people); according to the information of the Most Reverend Innocent, for the same period in the Pskov diocese 4.583 Uniates (in 1781 - 4.402, in 1783 - 181 people) (Kojalovič 1873,213 ) joined Orthodoxy, i.e. in the years 1781-1783, 117.161 Uniates returned to the Russian Church. Since at the time of the first partition of Poland there were approximately 800 thousand Uniates in the territories annexed to Russia (Lušpaj 2002, 105), by 1784 at least $14.6 \%$ of them had become Orthodox. During the second and third partitions, more Greek Catholics were reunited with the Russian Church in Malorossiya in the Bratslav, Izyaslav, and Volyn provinces (Ku- 
tejnikov 1888, 668; Bulgakov 2000, 328). From the end of August to the beginning of October 1794, 333.093 Uniates joined Orthodoxy (721 Uniate parishes together with 463 priests); in the following months, up to the end of February 1795, other 1.009.290 people joined (1.607 parishes with 1.032 priests, as well as two Basilian monasteries with 45 monks). Then, from February 28 to March 13, 1795, other 140.728 Uniates were returned, which amounted to 275 parishes with 57 priests (Kojalovič 1873, 361-363). Therefore, up to the spring of 1795, the Russian Orthodox Church was replenished by more than one million six-hundred thousand new parishioners. The total number of those who returned by the end of Catherine's reign was at least two million people (Dobroklonskij 2001, 652).

In historiography, the number of Uniates and Roman Catholics reunited with Orthodoxy has always been the main proof of the desire of the Uniates to return to the bosom of the Orthodox Church. However, historians, reconstructing the process of reunification, almost always utilized official data of the Russian spiritual department and provincial chancellery, which allow us to evaluate the outcome of the process of Orthodoxy, but not its complexity. At the same time, the practice of reunification had many contradictions, which are shown in memoirs, still almost unused in special works on the history of Orthodoxy and Catholicism in former (divided) Polish territories.

\section{The conversion of the Uniates to Orthodoxy according to the memoir sources}

Despite the impressive quantitative indicators characterizing the reunification of the Uniates with the Orthodox Church, the attitude towards the Union and the Latin rite was not the same in all areas and in all villages of the former Eastern Poland. For example, the highest number of voluntary appeals was found in the Bratslav Diocese, whose inhabitants relied on the Orthodox Church of the Left-Bank Malorossiya. In the same places where the Union took deep roots (for example, in Belarus and Volyn), the reunifications could be forced or even directly violent in nature (Smolič 1997, 324; 331; Shchapov 1998, 160). The notes of Gavriil Ivanoivch Dobrynin, lawyer of the Mogilev upper district court (later the provincial prosecutor), eloquently describes the complexities of the return of Belarusian Uniates to Orthodoxy.

In 1793, Mogilev governor Cheremisinov and Mogilev bishop Afanasy Volhovskiy received a Synodal order that officials in different counties should be sent to different districts for agitation to encourage the Uniates to join the Greek faith. One of these officials was responsible for agitating the residents of Senno County and authored many notes. Dobrynin described his missionary trip in his memoirs, ironically calling him an »apostolic survey«:

»In all there are 33 Uniate churches in the entire Senno district, all of which we visited (together with a zemstvo police officer and an Orthodox pri- 
est). To every church we gathered parishioners, at each church we read to them orders and instructions, asked about their free disposition to change faith, or, better to say, just to rename the faith. They exhorted them through a spiritual deputy and there wasn't a single soul wishing to lag behind the Uniate and stick to the Greco-Russian church.» $(1871,309)$

For three weeks Dobrynin tried to influence the Uniates, but he was forced to return to Mogilev with nothing. According to Dobrynin's own admission, he tried to act in strict accordance with the law: "Going to the city of Senno and knowing from the nominal imperial command that it is ordered to ask >Do not they wish to? ? and that it is forbidden to keep those who wish from their desires, I tried not to depart from the precise meaning of this prescription." (309) As a result, the official received a reprimand from secular and spiritual leaders who demanded to act more resolutely, "was everywhere declared by governor and bishop as an atheist and disobedient « (310). Other officials were quicker and applied pressure. In the source we read: "Someone informed us: he returned one church, two, three. And only the provincial government will receive such a report, when, on the other hand, it receives others from the Uniate clergy, from the parishioners, and the side roads and from the landlords - that the Uniates are forced to be beaten, that the church is returned by force, etc." (311).

The government Senate demanded an early resolution of the problem, so Cheremisinov decided to take extreme measures, demanding that the director of the economy, who was on business in the neighboring Bykhov Uyezd, convert the locals. The director admonished and persuaded the Bykhov Uniates, but when he began to threaten, the residents sounded the alarm, a crowd rushed in and shouted, "from which the director of the economy saw that they were angry". Then the governor himself came out with a cannon and gunners to subdue the riot. Negotiations of Cheremisinov with a man from the crowd show real religious preferences: "Why don't you wish to convert? « asked the governor. The man replied, "You seem to be kind, our faith is the same, the same Christian. And would you praise me, if I took one cross in my hands, and threw another under my feet? « to which the governor responded: "But why should you not be of one faith with me? "The man answered: "You yourself know well, already a man no longer young, if you were ordered to take our faith, would you want to be a Uniate?«, after which the governor gave the order to turn the cannon (312-313).

Another memoirist, Pafnutij Sergeevich Baturin, who served at the time as chairman of the Chamber of Civil Law, then the Chamber of Criminal Court in the city of Zhytomyr in the Volyn region, declared with all ardor that in 1794 the provincial officials were instructed to »turn the Uniates and their church into Greek Orthodoxy." (Baturin 1918, 105) Almost immediately resistance began to such preemptory policies: a huge number of cases were submitted to Baturin, »relating to indignation and opposition to the spread of the Russian faith «. The chairman admitted that such cases, »in their quantity and essence", caused him great difficulties, although he »tried as much as possible to burden less the fate of the 
defendants, for the most part their crimes were due to stupidity and ignorance, and denunciations against them - from anger and types of greedy individuals" (105). In the opinion of the secular man, conviction in the rightness of one's belief could indeed be perceived as "stupidity and ignorance", but in the conditions of the Russian legal relations of the period under study "stupidity " was punishable too. In particular, Baturin's memoirs indicate that resistance to reunification in some cases could be regarded as "evil intentions against Russia " and to be prosecuted administratively and criminally (105-108).

Violence in conversions to Orthodoxy, however, was strictly prohibited in the instructions of the governors. A special decree to Lieutenant-General T. I. Tutolmin, who served as Governor-General of Minsk, Izyaslavsky, and Bratslavsky, gave the order to act very circumspectly (Lušpaj 2002, 107). In materials of the State Council for 1795, Catherine II's decision to issue life-long maintenance in the amount of 100 rubles a year to the "Uniate priests, who, by not wishing to accept piety with the parishes, remained without seats « was upheld (Arhiv gosudarstvennogo soveta 1869,18$)$. However, the order of Orthodoxy remained voluntarycompulsory and did not exclude pressure on the clergy and landowners, on whom the religious affiliation of the peasantry depended (Vicissitudes de l'Eglise catholique des deux rites en Pologne et en Russie 1843, 199-218). Thus, the villages of the Uniate archbishop were sequestered »because of their refusal of the Uniate Church to join the Orthodox Greek Church « (Baturin 1918, 111). In the sequestration the estates of certain landowners were also taken, preventing the reunification of the Uniates (Dobrynin 1871, 307).

In 1798, a new imperial decree was issued by »instruction of spiritual persons, so that they would not force the Uniate law of the inhabitants to accept the Greek faith by any means " (RSHA 1798, 64). The decree was preceded by a report by Minsk governor Z. Ya. Karneev, who in June 1797 made an expedition trip to twenty-three priests, "where the people turned to piety are vacillating in the confession of faith " (Karneev 1869, 1559-1560). It turned out that all the "wavering" parishes were surrounded by the Uniates, and their members had a hope that "after them other villages would turn, and they would not lose the old relationship between kinship and acquaintance«, although mass conversions to Orthodoxy did not happen (1560). The Uniates hoped sto reduce all taxes and work, which may be inadvertently offered by the requestors «. Finally, many Uniates were enrolled in Orthodoxy without being consulted. As a result, almost none of the new converts went to Orthodox churches to order services for two or more years. Many of them resorted to Uniate sacraments or waccepted the Roman Catholic confession of faith, for example, in the two parishes of the Vileika district all residents did so" (1561). Orthodox priests, having lost income from fulfilling services, »insulted the people, forcing them against their will to go to church and receive the services and bringing forth complaints without reason on debauchery to the Uniate priests in the neighborhood, which caused many troubles, and the majority of the people were subject to torture without guilt« (1561). The governor stressed that although earlier there was a coercive factor on the part of the Uniate clergy 
and the Catholic nobility, now this factor had completely lost its meaning, and those who "vacillate in piety" wish to leave the Orthodox parishes voluntarily. Karneev formulated the main reasons for the "popular deviation from the church «: the excessively steep and »unsophisticated « nature of appeals to Orthodoxy when the priests attempted to give former Uniate temples the character of external piety, but did not take into account the spiritual needs of the people, demonstratively violating the established local ecclesiastical traditions in striving "to purify" the rites; the feeling of isolation of Orthodox neophytes from their fellow-countrymen and relatives of the Uniate religion from neighboring villages and the lack of "good will of the villagers to accept piety" also affected them (1561-1563). Of great importance was the authority of the Roman and Uniate priests, who, according to the governor, "this place's residents, having great faith and reverence toward Roman Catholic priests or their own priests, are ready to follow everywhere" (1566). As a result, in 1798, Karneev again was sadly forced to state that »in many villages, the former Uniate churches have been turned into pious ones, and priests have been identified, but the inhabitants in those churches go to receive sacrificial worship, despite the fact that most of them never had the voluntary desire to leave the union « (RSHA 1797, 2). Thus, the statement of the greatest pre-revolutionary Russian church historian, Archbishop Filaret (Gumilevsky), shared by many modern researchers, that »Russia has not heard a single complaint from the Uniates to their unwilling conversion to Orthodoxy « (Filaret 2001, 759), is groundless.

\section{Conclusion}

One cannot unequivocally agree with the conclusions of a number of modern scholars who assert that "the majority of the population of Belarus (and the Uniates in particular) were guided by Russianness, while remaining faithful to the cultural traditions of Eastern Slavs", and "powerful Western influence, which these lands experienced for centuries /... /, had an external character, not penetrating into the depths of popular perception « (Karev 1994, 23-24). Strong Orthodox traditions, indeed, were the most important factor in the spiritual reunification of the inhabitants of the former Polish territories with Russia. However, it is impossible to deny the authority and strength of Western Christian traditions in their spiritual life. It was this authority that caused the protest of a part of the Uniate population against the policy of Orthodoxy. Many Orthodox peasants in Belarus and Lithuania in the second half of the eighteenth and early nineteenth century continued to be influenced by the Catholic Church and its teachings, performing Orthodox rites in the Catholic manner: "The Orthodox flock of Belarus has learned some Latin rituals, such as pouring a sacrament of baptism, and raised complaints if the clergy baptized their children through immersion, also learned the Latin way of crossing themselves. " (Moroškin 1867, 38) In Podolia, the Orthodox at the same time "visited their Orthodox and Uniate neighboring church or the Catholic 
church /... /, baptized some children from Orthodox priests, and others from the Uniates, in short, to each of these religions the people brought part of their religious zeal on the grounds that in each of these churches the same God and the same Jesus Christ is believed in « (Simaškevič 1872, 404).

The attitude towards Unionism in the Polish provinces which joined Russia at the end of the eighteenth century was ambiguous. In West-Russian regions, sharp conflicts often arose between Catholics, Uniates, and Orthodox, but the initiators of these conflicts were mainly clerics. In the peasant environment, the attitude towards Catholicism, which became dominant in the spiritual culture of all classes, did not always imply hostility. Falling under the strong influence of the Uniate Church with the help of the Polish Roman Catholic Church, Belarusian, Russian, and Malorossian peasants developed a loyal attitude towards it, "fused « with it. The clashes between the Orthodox and Catholics that existed for a long time in Poland were largely political and fueled, on the one hand, by the Russian government, and, on the other hand, by Catholic Poland. The Malorossian and Belarus peasants initially were not inclined to confessional conflicts, which is confirmed by the preservation in this social environment of a positive attitude towards Catholicism and Unionism even after the annexation of the eastern territories of the Polish Commonwealth to Russia.

\section{References}

Anisimov, Vasilij, Aleksandr Danilevskij, and Vladislav Djatlov. 2007. Pravoslavie i katolitsizm v Ukraine. Kratkaja hronika sobytij [Orthodoxy and Catholicism in Ukraine. A Brief Chronicle of Events]. Novaja kniga Rossii, no. 3:1924.

Arhiv gosudarstvennogo soveta. 1869. Vol. 1, part 2. Saint-Petersburg: 2nd Branch of His Imperial Majesty's Office.

Bantysh-Kamenskij, Nikolaj. 1864. Istoricheskoe izvestie o voznikshej v Pol'she unii [Historical News of the Church Union that Arose in Poland]. Vilnius: Printing House A. Syrkin.

Baturin, Pafnutij Sergejevič. 1918. Zhizn' i pohozhdenija gospodina statskogo sovetnika Baturina. Povest' spravedlivaja, pisannaja im samim [Life and Adventures of Mr. State Councilor Baturin. A Fairy Tale Written by Himself]. Golos minuvshego [The Voice of the Past], no. 7/9:99132.

Borisjonok, Jurij Arkadjevič. 2003. Belorussko-russkoe pogranich'e v uslovijah Rossijskoj imperii (vtoraja polovina XVIII - pervaja polovina XIX vekov) [Belarusian-Russian Borderlands in the Conditions of the Russian Empire (Second Half of 18th - First Half of 19th centuries)]. Voprosy istorii, no. 3:116-122.
Bulgakov, Mikhail. 2000. Preosvjashhennyj Georgij Konisskij, arhiepiskop Mogilevskij [Archbishop of Mogilev Geroge Konissky]. Minsk: Vinograd.

Dobroklonskij, Aleksandr Pavlovič. 2001. Rukovodstvo po istorii Russkoj Tserkvi [A Guide to the History of the Russian Church]. Moscow: Patriarchal podvorye of Krutitskoe.

Dobrynin, Gavriil. 1871. Istinnoe povestvovanie, ili zhizn' Gavriila Dobrynina, im samim pisannaja. 1752-1823 [The True Narrative, or the Life of Gabriel Dobrynin, written by himself]. Russkaja starina, no. 4:305-372.

Filaret (Gumilevskij, Dmitrij Grigorievič), archbishop. 2001. Istorija Russkoj Tserkvi v pjati periodah [History of the Russian Church in Five Periods]. Moscow: Sretensky monastery.

Giltebrandt, Piotr Andreevič. 1870. Vasko-Vozchilo, vnuk Bohdana Chmielnickogo [Vasko-Vozchilo, a grandson of Bogdan Chmielnicki]. Russkaja starina, no. 2:522-524.

Grigorovič, Nikolaj Ivanovič. 1869. Iz bumag mitropolita Novgorodskogo i Sankt-Peterburgskogo Gavriila [From the papers of Metropolitan Gabriel of Novgorod and St. Petersbug]. Russkij arhiv, no. 10:1569-1650.

Iz bumag protoiereja Ioanna Pamfilova (duhovnika imperatritsy Ekateriny II) [From the papers 
of Archpriest Joann Pamfilov (the Confessor of the Empress Catherine II)]. 1871. Russkij arhiv, no. 1:201-237.

Karev, Dmitrij Vladimirovič. 1994. Latinjane i skhizmatiki [Latins and Schismatics]. Rodina, no. 12:21-24.

Karneev, Zakharij Jakovlevič. 1869. Vsepresvetlejshemu Velikomu Gosudarju imperatory ot dejstvitel'nogo statskogo sovetnika Minskogo gubernatora Karneeva vsepoddannejshij raport [A Loyal Report of the Acting State Councilor and Minsk Governor Karneev, Submitted to his Highness the Great Emperor]. Russkij arhiv, no. 9:1559-1566.

Kojalovič, Mikhail Osipovič. 1873. Istorija vossoedinenija zapadnorusskih uniatov staryh vremjon [The History of the Reunification of Western Russian Uniates of Old times]. Saint-Petersburg: 2nd Branch of His Imperial Majesty's Office.

Kutejnikov, Nikolaj Stepanovič. 1888. Kolybel' khristianstva v Rossii [The Cradle of Christianity in Russia]. Istoricheskij vestnik [Historical Bulletin] 32, no. 6:659-676.

Lušpaj, Vladimir Borisovič. 2002. lezuity v Rossii vtoroj poloviny XVIII veka: Dissertatsija kandidata istoricheskih nauk [Jesuits in Russia in the Second Half of the 18-th century: Dissertation for Candidate Sciences (History)]. Moscow.

Maraš, Jakov Naumovič. 1971. Vatikan i katolicheskaja tserkov'v Belorussii [The Vatican and the Catholic Church in Belarus]. Minsk: Vyshejsha shkola.

Moroškin, Mikhail Jakovlevič. 1867. lezuity v Rossii s tsarstvovanija Ekateriny II i do nastojashhego vremeni [Jesuits in Russia From the Reign of Catherine II Until the Present Time]. Part 1. Saint-Petersburg: 2nd Branch of His Imperial Majesty's Office.

Polnoe sobranie zakonov Rossijskoj imperii. Sobranie pervoe [The Complete Collection of Laws of the Russian Empire (Collection 1)] (in 50 vols.). 1830 . Vol. 20, no. 15 028). Saint-Petersburg: 2nd Branch of His Imperial Majesty's Office.

RSHA 1797 - Russian State Historical Archive, Chancery of the Holy Synod, 1797 year. F. 796. Op. 78. File 604.

RSHA 1798 - Russian State Historical Archive, Chancery of the Holy Synod, 1798 year. F. 796. Op. 79. File 813.
RSHA 1772a - Russian State Historical Archive, Chancery of the Greek Uniate churches' metropolitans, 1772 year. F. 823. Op. 2/2. File 2056.

RSHA 1772b - Russian State Historical Archive, Chancery of the Greek Uniate churches' metropolitans, 1772 year. F. 823. Op. 2/2. File 2070.

Simaškevič, Mitrofan Vasiljevič. 1872. Rimskoe katolichestvo i ego ierarhija v Podolii [Roman Catholicism and its Hierarchy in Podolia]. Kamenec-Podolsky: Podolsk provincial Board.

Shchapov Jaroslav Nikolaevič, Olga Jurjevna Vasilieva, and Pavel Nikolaevič Zyrjanov. 1998. Khristianskie veroispovedanija i gosudarstvennaja vlast' v Rossii v XVIII - pervoj polovine $X X$ veka [Christian Confessions and State Power in Russia in the $18^{\text {th }}$ century through the first half of the $20^{\text {th }}$ century]. Otechestvennaja istorija [National history], no. 3 :155-163.

Smolič, Igor' Korniljevič. 1997. Istorija russkoj tserkvi. 1700-1917 [History of the Russian Church. 1700-1917]. In: Istorija russkoj tserkvi [History of the Russian Church], book 8, part 2, 2-799. Moscow: The Savior of the Transfiguration Valaam monastery.

Stegnij, Petr Vladimirovič, 2001. Pervyj razdel Pol'shi i rossijskaja diplomatija [The first section of Poland and Russian diplomacy]. Novaja i novejshaja istorija [New and Recent History], no. 1:152-174.

Vicissitudes de l'Eglise catholique des deux rites en Pologne et en Russie. 1843. Ouvrage écrit en Allemand, par un prêtre de la Congrégation de l'oratoire, précedé d'un avant-propos par le comte de Montalembert, pair de France. Vol. 1. Paris: Ancienne maison debécourt; Sagnier et Bray.

Zaborovskij, Lev Valentinovič. 1998. Katoliki, pravoslavnye, uniaty: Problemy religii v russko-polsko-ukrainskih otnoshenijah kontsa 40-h -80-h godov XVII veka. Dokumenty. Issledovanija [Catholics, Orthodox, Uniates: The Problems of Religion in Russian-Polish-Ukrainian Relations of the Late 1640s-1680s.]. Part 1. Moscow: Pamjatniki istorichekoj mysli. 